\title{
Intradural conus and cauda equina tumours: a retrospective review of presentation, diagnosis and early outcome
}

\author{
Peter Mathew, Nicholas V Todd
}

\begin{abstract}
This is a retrospective review of the clinical presentation, diagnosis and management of 62 patients with histologically proven intradural conus and cauda equina tumours. In the majority of cases the clinical presentation clearly suggests the need for further investigation. One fifth of the patients had small intramedullary tumours, which presented particular diagnostic difficulty and required sophisticated cross sectional imaging.
\end{abstract}

(F Neurol Neurosurg Psychiatry 1993;56:69-74)

Conus and cauda equina tumours present a varied clinical picture. Attempts to distinguish conus from cauda equina lesions have been made clinically, but many authors believe the distinction is of little value. ${ }^{1-4}$ The predominant symptoms and signs of these tumours are well documented. ${ }^{45} \mathrm{~A}$ high proportion of tumours in this region are benign. However, prognosis after treatment depends not only on histology but also on the degree of neurological deficit before operation, and the importance of early diagnosis and subsequent treatment is well recognised. ${ }^{6}$ The emphasis of this paper is on the clinical presentation and indications for investigation of these tumours.

\section{Patients and methods}

We retrospectively audited the clinical presentation, management, pathology and prognosis of 62 patients who, between 1971-89 had an operation at the Institute of Neurological Sciences, Glasgow, for a solitary intradural tumour arising in the conus, cauda equina or filum terminale. We included patients with solitary tumours only. Patients with vascular anomalies were excluded, as were patients with multiple neurofibroma at several levels, and holocord tumours, even if part lay within the conus region.

The case notes were reviewed. The nature and duration of symptoms and signs, and the investigations carried out before surgery were documented, as was the surgical approach, completeness of excision of tumour, histology and subsequent outcome. The length of follow up was determined by the date of the last available record in the clinical notes. Outcome after operation was assessed from the clinical records, symptomatically in terms of pain, paraesthesia, subjective lower limb weakness and sphincter disturbance, and by objective neurological examination.

\section{Results}

Between 1971-89 the total number of histologically diagnosed spinal tumours was 853 , of which $123(14.4 \%)$ were conus and cauda equina tumours. Of these conus and cauda equina tumours, 61 were extradural, and 62 , representing the study population, were intradural. Case notes for six patients (histological diagnosis of epidermoid in three, dermoid in two and glial tumour in one, were missing). The 56 patients remaining are the basis of this report. Of these, 25 were predominantly or wholly intramedullary (within the conus medullaris) and 31 were predominantly or wholly extramedullary.

\section{Tumour type}

Patients with neurofibroma and glial tumours each comprised almost one quarter of the sample. Dermoid and epidermoid tumours and teratomas made up over one third of the sample (table 1).

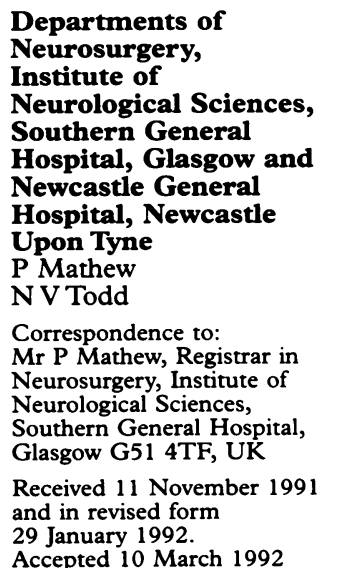

Table 1 Population characteristics of the sample

\begin{tabular}{|c|c|c|c|c|c|c|c|}
\hline & \multirow[b]{2}{*}{$N$} & \multirow[b]{2}{*}{$\%$} & \multicolumn{2}{|l|}{ Age } & \multirow{2}{*}{$\begin{array}{l}\text { Median duration } \\
\text { of symptoms } \\
\text { (months) }\end{array}$} & \multirow{2}{*}{$\begin{array}{l}\text { Range } \\
\text { (months) }\end{array}$} & \multirow[b]{2}{*}{$M: F$} \\
\hline & & & Median & Range & & & \\
\hline $\begin{array}{l}\text { Neurofibroma } \\
\text { Glial tumour }\end{array}$ & 15 & 24 & 50 & $23-75$ & 12 & $(3-144)$ & $7: 8$ \\
\hline $\begin{array}{l}\text { Glial tumour } \\
\text { (a) Ependymoma } \\
\text { (b) Astrocytoma }\end{array}$ & $\begin{array}{l}7 \\
6\end{array}$ & $\begin{array}{l}(11) \\
(10)\end{array}$ & $\begin{array}{l}37 \\
25\end{array}$ & $\begin{array}{r}9-52 \\
12-47\end{array}$ & $\begin{array}{l}3 \\
2\end{array}$ & $\begin{array}{l}(1-36) \\
(1-2)\end{array}$ & $\begin{array}{l}6: 1 \\
1: 1\end{array}$ \\
\hline $\begin{array}{l}\text { Congenital midline tumour } \\
\text { (a) Dermoid } \\
\text { (b) Epidermoid } \\
\text { (c) Teratoma } \\
\text { (d) Lipoma }\end{array}$ & $\begin{array}{r}11 \\
9 \\
3 \\
3\end{array}$ & $\begin{array}{l}(17) \\
(14 \cdot 5) \\
(5) \\
(5)\end{array}$ & $\begin{array}{r}12 \\
8 \\
16 \\
20\end{array}$ & $\begin{array}{l}2-59 \\
3-41 \\
6-18 \\
5-36\end{array}$ & $\begin{array}{l}6 \\
2 \cdot 5 \\
2 \\
30\end{array}$ & $\begin{array}{r}(2-48) \\
(1-96) \\
(5-30) \\
(24-36)\end{array}$ & $\begin{array}{l}4: 6 \\
1: 1 \\
2: 1 \\
2: 1\end{array}$ \\
\hline $\begin{array}{l}\text { Others } \\
\text { (a) Meningioma } \\
\text { (b) Arachnoid cyst } \\
\text { (c) Malignant melanoma } \\
\text { (d) Meningeal cyst } \\
\text { Total }\end{array}$ & $\begin{array}{r}4 \\
1 \\
2 \\
1 \\
62\end{array}$ & $\begin{array}{l}(6) \\
(1 \cdot 5) \\
(3) \\
(1 \cdot 5) \\
100\end{array}$ & $\begin{array}{l}62 \\
54 \\
13\end{array}$ & $\begin{array}{l}\frac{28-66}{55}-58 \\
-\end{array}$ & $\begin{array}{r}9 \\
\frac{2}{15}\end{array}$ & $\begin{array}{l}(3-9) \\
-(1-6)\end{array}$ & $\begin{array}{l}1: 1 \\
F \\
2: 0 \\
M\end{array}$ \\
\hline
\end{tabular}


Clinical Presentation

Clinical findings at the time of presentation to a specialist are documented in table 2. Back pain was present in over half of the patients; leg pain (either unilateral or bilateral) was also present in over half. Leg weakness was present in one quarter, bladder dysfunction in one third, and bowel dysfunction in one in 15 patients. Four patients (all with tumours invading the conus medullaris) had back pain as the only clinical problem at the time they presented to a specialist. Patients with tumours involving the cauda equina only, were more likely to have unilateral radicular pain at presentation than tumours invading the conus medullaris (see table 3 ). Tumours invading the conus medullaris were more likely to cause sphincter dysfunction. In almost half the patients with conus medullaris tumour, and a quarter of patients with cauda equina tumour, back pain or leg pain was absent. Half of the patients who had epidermoid tumours had a past history of meningitis, and one third had a visible cutaneous abnormality (sinus and superficial cyst). For the dermoid group these proportions were one tenth and one fifth respectively.

Investigations (table 4)

Plain radiographs were carried out in all patients. Only nine patients demonstrated an abnormality, usually a variant of spina bifida occulta. All patients had myelography; this was abnormal in all cases except one (of dermoid tumour), but was diagnostic in less than one third. Only 10 patients (the most recent) had sophisticated cross-sectional imaging. However, CT scanning (in 5 patients ) did not improve upon the diagnostic accuracy of myelography. MRI scanning (in 5 patients) was diagnostic for all 3 patients with dermoid tumour, but not diagnostic in one patient with a glial tumour and a further patient with a neurofibroma.

Management and early outcome (table 5)

Comparison in each histological group between those patients managed in the first 9 years and those in the last 9 years of the review period did not reveal significant differences in outcome.

\section{Neurofibroma}

All 15 patients had laminectomy and attempted complete tumour removal, but complete excision could not be achieved in two cases. Nine of 11 patients with back pain were improved after operation. Weakness and sensory loss did not improve postoperatively in any patient. One patient died and necropsy histology revealed sarcomatous change in a recurrence at the site of the previously macroscopically completely excised tumour.

\section{Glial tumours}

All 12 patients had laminectomy and decompression; 10 had subtotal excision and macroscopically complete excision was judged to have been achieved in two cases. Eight of nine patients complaining of back or leg pain on admission reported an improvement in their pain postoperatively. Of the seven patients with leg weakness, four improved after operation, and three became paraparetic. Sphincter dysfunction, present in seven patients on admission was not improved by operation. Operation was followed by radiotherapy in all patients with sub-total excision, (with the exception of one incompletely excised low grade astrocytoma), and did not result in improvement in post-operative neurological status.

\section{Congenital midline tumours}

Complete excision of the tumour was carried out in six of 21 patients. Dermoid: Back pain and/or leg pain, present in four patients at admission was relieved in all cases by operation. Two out of five patients presenting with leg weakness had objective improvement after operation. Of the six patients presenting with sphincter dysfunction at admission, half were improved, and half were unchanged after the operation. Epidermoid teratoma and lipoma: Only one of three patients with epidermoid

Table 2 Clinical presentation related to histology (excludes missing data-4 congenital midline tumours and 1 glial tumour (Number (percentage) of patients)

\begin{tabular}{|c|c|c|c|c|c|c|c|c|c|c|c|c|}
\hline & \multirow[b]{2}{*}{$N$} & \multirow[b]{2}{*}{ Back } & \multicolumn{2}{|l|}{ Pain } & \multirow{2}{*}{$\begin{array}{l}\text { Neither } \\
\text { back } \\
\text { nor } \\
\text { leg }\end{array}$} & \multicolumn{2}{|c|}{ Weakness* } & \multirow{2}{*}{$\begin{array}{l}\text { Upper } \\
\text { motor } \\
\text { neuron } \\
\text { signs }\end{array}$} & \multicolumn{2}{|c|}{$\begin{array}{l}\text { Root } \\
\text { involvement }\end{array}$} & \multicolumn{2}{|c|}{$\begin{array}{l}\text { Sphincter } \\
\text { involvement }\end{array}$} \\
\hline & & & $\begin{array}{l}\text { One } \\
\text { Leg }\end{array}$ & $\begin{array}{l}\text { Both } \\
\text { legs }\end{array}$ & & $\begin{array}{l}\text { One } \\
\text { leg }\end{array}$ & $\begin{array}{l}\text { Both } \\
\text { legs }\end{array}$ & & Single & $>1$ & Bladder & Bowel \\
\hline $\begin{array}{l}\text { Neurofibroma } \\
\text { Glial tumour } \\
\text { Congenital midline }\end{array}$ & $\begin{array}{l}15 \\
12\end{array}$ & $\begin{array}{l}9(60) \\
8(67)\end{array}$ & $\begin{array}{r}10(67) \\
2(17)\end{array}$ & $\begin{array}{l}1(7) \\
4(33)\end{array}$ & $\begin{array}{l}4(27) \\
4(38)\end{array}$ & $\begin{array}{l}3(20) \\
3(25)\end{array}$ & $\begin{array}{l}2(13) \\
4(33)\end{array}$ & $\begin{array}{l}0 \\
0\end{array}$ & $\begin{array}{l}4(27) \\
2(17)\end{array}$ & $\begin{array}{l}7(47) \\
8(67)\end{array}$ & $\begin{array}{l}1(17) \\
8(67)\end{array}$ & $\begin{array}{l}0 \\
2(17)\end{array}$ \\
\hline $\begin{array}{l}\text { tumour } \\
\text { Others } \\
\text { All }\end{array}$ & $\begin{array}{r}21 \\
8 \\
56\end{array}$ & $\begin{array}{r}9(43) \\
6(75) \\
32(57)\end{array}$ & $\begin{array}{r}2(10) \\
4(50) \\
18(32)\end{array}$ & $\begin{array}{r}4(20) \\
2(25) \\
11(20)\end{array}$ & $\begin{array}{r}9(43) \\
1(12) \\
18(32)\end{array}$ & $\begin{array}{r}4(19) \\
4(50) \\
14(25)\end{array}$ & $\begin{array}{r}9(43) \\
1(12) \\
16(29)\end{array}$ & $\begin{array}{l}4(19) \\
1(12) \\
5(9)\end{array}$ & $\begin{array}{r}4(19) \\
1(12) \\
11(20)\end{array}$ & $\begin{array}{r}10(48) \\
6(75) \\
31(55)\end{array}$ & $\begin{array}{r}8(38) \\
3(37) \\
17(30)\end{array}$ & $\begin{array}{l}1(5) \\
1(12) \\
4(7)\end{array}$ \\
\hline
\end{tabular}

Either objective or subjective weakness alone, or both.

Table 3 Clinical presentation related to site of tumour (Number (percentage) of patients)

\begin{tabular}{|c|c|c|c|c|c|c|c|c|c|c|c|c|}
\hline & \multirow[b]{2}{*}{$N$} & \multirow[b]{2}{*}{ Back } & \multicolumn{2}{|l|}{ Pain } & \multirow{2}{*}{$\begin{array}{l}\text { Neither } \\
\text { back } \\
\text { nor } \\
\text { leg }\end{array}$} & \multicolumn{2}{|c|}{ Weakness* } & \multirow{2}{*}{$\begin{array}{l}\text { Upper } \\
\text { motor } \\
\text { neuron } \\
\text { signs }\end{array}$} & \multicolumn{2}{|c|}{$\begin{array}{l}\text { Root } \\
\text { involvement }\end{array}$} & \multicolumn{2}{|c|}{$\begin{array}{l}\text { Sphincter } \\
\text { involvement }\end{array}$} \\
\hline & & & $\begin{array}{l}\text { One } \\
\text { Leg }\end{array}$ & $\begin{array}{l}\text { Both } \\
\text { legs }\end{array}$ & & $\begin{array}{l}\text { One } \\
\text { leg }\end{array}$ & $\begin{array}{l}\text { Both } \\
\text { legs }\end{array}$ & & Single & $>1$ & Bladder & Bowel \\
\hline \multirow{2}{*}{$\begin{array}{l}\text { Tumour invading conus } \\
\text { medullaris } \\
\text { Tumour cauda equina } \\
\text { only }\end{array}$} & 25 & $13(52)$ & $3(12)$ & $6(24)$ & $10(40)$ & $7(28)$ & $8(32)$ & $4(16)$ & $2(8)$ & $15(60)$ & $9(36)$ & $3(12)$ \\
\hline & 31 & $19(61)$ & $15(48)$ & $5(16)$ & $8(26)$ & $7(22)$ & $8(36)$ & $1(3)$ & 9 (29) & $16(52)$ & $8(26)$ & $1(3)$ \\
\hline
\end{tabular}


Table 4 Outcome of investigations (Figures in parentheses are percentages)

\begin{tabular}{|c|c|c|c|c|c|c|c|c|c|c|c|c|}
\hline Histology & $N$ & Abnormal & Diagnostic & $N$ & Abnormal & Diagnostic & $N$ & Abnormal & Diagnostic & $N$ & Abnormal & Diagnostic \\
\hline $\begin{array}{l}\text { Neurofibroma } \\
\text { Glial tumour } \\
\text { Congenital midline tumour } \\
\text { Others } \\
\text { All }\end{array}$ & $\begin{array}{r}15 \\
12 \\
21 \\
8 \\
56\end{array}$ & $\begin{array}{l}0 \\
0 \\
9 \\
0 \\
9(17)\end{array}$ & $\begin{array}{l}0 \\
0 \\
0 \\
0 \\
0\end{array}$ & $\begin{array}{r}15 \\
12 \\
21 \\
8 \\
56\end{array}$ & $\begin{array}{l}15 \\
12 \\
21 \\
8 \\
56(100)\end{array}$ & $\begin{array}{l}5 \\
2 \\
9 \\
0 \\
16(29)\end{array}$ & $\begin{array}{l}1 \\
1 \\
3\end{array}$ & $\begin{array}{l}1 \\
1 \\
3\end{array}$ & $\begin{array}{l}0 \\
0 \\
0\end{array}$ & $\begin{array}{l}1 \\
1 \\
3\end{array}$ & $\begin{array}{l}1 \\
1 \\
3\end{array}$ & $\begin{array}{l}0 \\
0 \\
3\end{array}$ \\
\hline
\end{tabular}

tumour presenting with pain was improved by operation. Of the four patients presenting with lower limb weakness, two were improved after the operation. Back pain was present in all three patients who had teratoma, and improved by operation in two cases, despite incomplete excision in one. Both patients with lipoma presented with sphincter disturbance on admission which persisted unchanged after incomplete excision of the tumour.

\section{Others}

Two of the four patients with meningioma had macroscopically complete excision of the tumour; both had improvement in, but not complete relief of, back and leg pain. One patient had incomplete removal and no improvement in the symptoms; one patient had multiple operations for recurrent haemangiopericytoma. Both patients with malignant melanoma had sub-total decompression, in one case followed by radiotherapy. Neither were clinically improved, and both died rapidly from metastasis. Both patients with an arachnoid cyst and meningeal cyst were completely relieved of back pain after complete excision of the cyst.

\section{Discussion \\ Methods}

This is a retrospective review with the disadvantages of lost case notes and inaccuracy of the recording of symptoms, signs and operation notes. However, it has the advantage of bringing together a relatively large series of patients with conus and cauda equina tumours. The catchment area of the Institute of Neurological Sciences is large (2.7 million people) and probably all patients with a tumour in this region requiring operation have been included. On average this population will yield one patient with an intradural conus or cauda equina tumour every 3.5 months.

Tumour type and frequency

These tumours (both intradural and extradural) represent approximately $20 \%$ of all spinal tumours. Over two thirds of extradural tumours are metastases. ${ }^{7}$ The frequency of different tumour types, sex incidence and age distribution of our 62 tumours are comparable with the other reported series of spinal cord tumours. Our patients are representative of tumours of this region as a whole. ${ }^{691011}$

Neurofibromas are the most common intradural, extramedullary tumours and those arising in this region represent approximately one quarter of spinal neurofibromas. ${ }^{612}$

Tumours which are wholly or partly intramedullary comprise a wide variety of lesions, some neoplastic and some congenital. Common examples include ependymoma, astrocytoma, and haemangioblastoma; the congenital lesions most commonly found are lipoma, intramedullary dermoids and epidermoids. Approximately $4 \%$ of all intramedullary tumours are found in this region; however, one half of spinal cord ependymomas are found at this site. ${ }^{9}$ The high frequency of ependymal tumours at this site may be accounted for by the high concentration of ependymal cells normally found around the region of the filum terminale. Astrocytomas arising in this region are relatively uncommon and account for only $4 \%$ of all spinal astrocytomas, with a greater tendency to be malignant. ${ }^{81314}$ Dermoid tumours, epidermoid tumours, teratomas and lipomas (the "congenital midline tumours") comprise approximately $10 \%$ of all intradural spinal cord tumours. ${ }^{15}$ However, dermoid tumours are particularly common during the first year of life, and at this age account for almost one fifth of primary spinal cord tumours. ${ }^{16}{ }^{17}$ Spinal dermoid and epidermoid tumours arise most frequently at the lumbar site. Our finding that one half of the dermoid tumours and one quarter of the epidermoid tumours were intramedullary, agrees with other authors. ${ }^{18}$

Meningiomas arising in the lumbosacral region are uncommon, and represent only $2 \%$ of all spinal cord meningiomas. ${ }^{81218}$ Overall, spinal cord meningiomas occur more frequently in females, but in the lumbosacral region the sex incidence is equal. ${ }^{1019}$

Clinical presentation-individual features

Precise preoperative diagnosis no longer needs

Table 5 Management and early outcome

\begin{tabular}{|c|c|c|c|c|}
\hline Histology & $\begin{array}{l}\text { Number with } \\
\text { complete excision }\end{array}$ & $\begin{array}{l}\text { Back andlor leg } \\
\text { pain improved }\end{array}$ & $\begin{array}{l}\text { Weakness } \\
\text { improved }\end{array}$ & $\begin{array}{l}\text { Sphincter function } \\
\text { improved }\end{array}$ \\
\hline $\begin{array}{l}\text { Neurofibroma } \\
\text { Glial tumours } \\
\text { Congenital midline tumours } \\
\text { Others } \\
\text { All }\end{array}$ & $\begin{array}{r}13 \\
2 \\
6 \\
4 \\
25\end{array}$ & $\begin{array}{c}9 / 11 \\
8 / 9 \\
7 / 11 \\
5 / 7 \\
29 / 38\end{array}$ & $\begin{array}{l}0 / 5 \\
4 / 7 \\
6 / 12 \\
3 / 5 \\
13 / 29\end{array}$ & $\begin{array}{l}0 / 1 \\
0 / 7 \\
2 / 8 \\
0 / 2 \\
2 / 18\end{array}$ \\
\hline
\end{tabular}

* Includes radiotherapy for 11 patients. 
to be based on clinical signs. However, an idea of which pathologies are likely and the site of pathology will guide subsequent imaging and treatment.

Pain

Other authors confirm that pain is the commonest presenting symptom of these tumours. It is usually insidious in onset, being initially poorly localised in the lower back, with progression to more clearly defined pain, radiating into one or both legs. ${ }^{3620}$ This progression was most clearly demonstrated in our series by patients with extramedullary tumour, in particular those with neurofibroma (almost three quarters), but was also seen in over half of the glial tumours. In sites other than the conus and cauda equina, it is rare for glial tumours to present with root pain. ${ }^{21}$ Pain in recumbency, waking patients at night and relieved by walking is classically due to root involvement by a cauda-equina tumour, in contrast to the pain from a herniated lumbar disc, which is characteristically eased by rest. ${ }^{4}$ These features were notably absent in this series, which may reflect the inadequacy of retrospective review or challenge classic presentations.

\section{Weakness}

Weakness of muscle groups innervated by one or more nerve roots is a common finding in patients with neurofibroma. Motor weakness is frequently present in intramedullary tumours, and this is due to the sensitivity of the anterior horn motor neurons to direct mechanical compression and ischaemia. ${ }^{22}$ Leg weakness as an isolated presenting symptom occurred in $13 \%$ of our patients with intramedullary tumour. However, in very slowly growing tumours, the incidence may be as high as $50 \%$. $^{23}$

\section{Sphincters}

Involvement of the lower sacral roots, or the conus itself, may produce disorders of sphincter function, which may precede other symptoms and/or signs by many months. This usually takes the form of inadequate bladder emptying and at the time of presentation is found in about half of the patients. ${ }^{36}$ The high incidence of early sphincter disturbance in patients with dermoid tumours found in this series is not confirmed by other authors. ${ }^{8} 18$

Sensory loss in the saddle region (seen in $9 \%$ of patients in our series, none as an isolated symptom) occurs in both intramedullary and extramedullary tumours. The sacral sparing of sensation that may distinguish intramedullary from extramedullary tumours of the cord at higher levels is not seen in this region. ${ }^{21}$ The finding of a patulous anus, not necessarily associated with saddle sensory loss, is of value in the early diagnosis of these tumours. ${ }^{24}$

\section{Cutaneous abnormalities}

The finding of a cutaneous anomaly in the region of the lumbosacral spine, demonstrated in up to $50 \%$ of patients with dermoid tumours in this region, is clearly of diagnostic significance. ${ }^{25}$

\section{Papilloedema}

No patients in this series demonstrated papilloedema which is a rare but recognised finding in spinal cord tumours. ${ }^{2627}$

\section{Subarachnoid haemorrhage}

This is a rare presentation of spinal tumour, but is almost always associated with a conus or cauda equina tumour. ${ }^{28}$

\section{Clinical presentation-symptom patterns}

In a review from Oxford (1978) half the patients with a cauda equina tumour presented between the fourth and fifth decade. This reflects the predominance of neurofibroma which occurs relatively commonly in this age group and in this region. ${ }^{6}$ The average duration of symptoms and age at presentation of spinal cord neurofibroma and meningioma are similar, being approximately 24 months and 53 years respectively. ${ }^{82}$ Patients with neurofibroma demonstrate a high proportion of unilateral radicular symptoms. Although patients with glial tumours show the same progression of dull back pain to more clearly defined leg pain, and indeed as many as half have unilateral symptoms, they present at a younger age (median age 30 years). The duration of symptoms of patients with glioma varies depending on tumour histology, with some series of malignant astrocytomas reporting a mean duration of symptoms of less than six months. Comparable figures for benign astrocytoma and ependymoma are 15 years and 56 months respectively. ${ }^{89}$ An average duration of symptoms for all spinal cord glial tumours is between seven and nine years. ${ }^{911}$ In our series, the mean duration of symptoms for all glial tumours was 8 months. This may reflect the greater percentage of ependymomas found in this region, and the increased tendency for malignant astrocytomas to arise here.

Patients with congenital midline tumours have a median age at presentation of 15 years, reflecting the predominance of dermoid tumours occurring in this group. Symptoms are bilateral in over one third of these patients.

\section{Clinical presentation-diagnostic difficulty}

Patients with back and leg pain and objective signs require further investigation. A small group of patients present diagnostic difficulty. These comprise patients complaining of back pain only (three patients all with intramedullary tumours), patients complaining neither of back nor leg pain, but of weakness, with no objective neurological signs (four patients with glial tumour) and patients with isolated disturbance in sphincter function only (two patients with intramedullary tumour). Patients who present with diagnostic difficulty all have small intramedullary tumours. These are the tumours most likely to be missed on lumbar myelography and in whom MRI will have the highest diagnostic yield (see below).

\section{Imaging}

The advent of MRI has revolutionised the 
investigation of conus and cauda equina tumours. When there is firm clinical evidence of such a tumour, and where MRI is available, this is the primary investigation of choice (fig $1)$.

Plain radiographs are still useful; bony changes (comprising enlargement of the spinal canal, posterior erosion of the vertebral bodies and spina bifida occulta of varying severity) are a common feature of the congenital midline tumours. ${ }^{1822}$

All clinically significant intradural, extramedullary tumours will be demonstrated by myelography, while small intramedullary conus tumours can be missed. When an intramedullary tumour produces complete obstruction, correct differential diagnosis from extramedullary tumours may be difficult. More frequently, the tumour produces a partial block, displacing the contrast column laterally; this appearance merely represents enlargement of the spinal cord, and distinction from myelitis, intramedullary granuloma, abscess, intramedullary haematoma or syr-

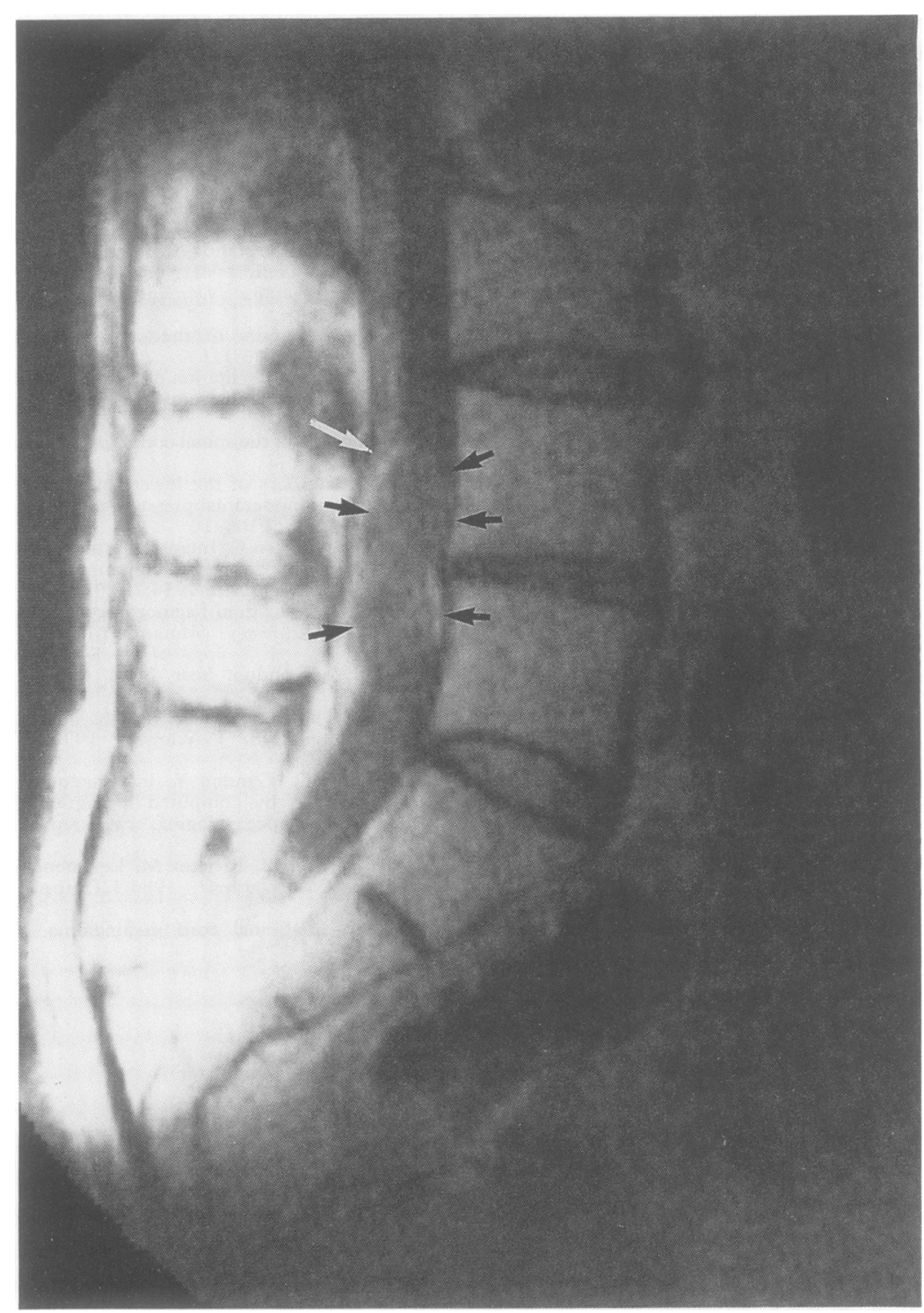

Figure $1 T 1$ weighted (SE700/32) enhanced (gadopentatate dimeglumine) sagittal image showing intradural swelling of the filum terminale (black arrows) opposite L4-S1 vertebral bodies. The roots of the cauda equina are displaced posteriorly (white arrow). ingomyelia may be impossible. ${ }^{29} \mathrm{MRI}$ will identify most clinically significant conus and cauda equina tumours and will usually also identify the nature of the tumour. Small intradural, extramedullary tumours are poorly seen on non-contrast MRI, and the use of gadolinium is essential, considerably enhancing even small lesions. MRI has revolutionised the evaluation of intramedullary spinal cord tumours. Contrast enhanced MRI improves their characterisation and delineation. Almost all tumours enhance, and gadolinium helps to separate the solid portion of tumours from adjacent oedema and associated cysts. ${ }^{30} 31$

\section{Technical considerations}

That comparison of outcome of operation between the first and last 9 year periods did not reveal significant differences almost certainly reflects the small numbers involved rather than the lack of impact of introduction of modern microsurgical techniques. It is not appropriate to discuss in detail the technical aspects of surgery in this article. Nevertheless, a few general points are appropriate.

Neurofibromas can usually be completely excised, albeit with sacrifice of the affected nerve root. Eighty five per cent of patients experience complete relief of pain, and $60 \%$ make a full functional recovery.

Meningiomas can be completely removed, with excision or coagulation of the dural attachment. The recurrence rate following complete macroscopic excision is $7 \% .^{1032}$ There is no clear correlation between late results and the extent of resection of the dural attachment. $^{1033}$

Dermoid and Epidermoid tumours can be macroscopically totally excised in up to $40 \%$ of cases (fig 2). ${ }^{18}$ This is reasonable, provided it is not associated with substantial morbidity, as partial removal can affectively relieve symptoms, often for many years, and in some cases permanently.

Ependymomas are usually benign tumours which tend to displace rather than infiltrate. There is usually a plane of cleavage between tumour and spinal cord, and complete excision can usually be achieved. Complete excision produces the best long term functional results. ${ }^{1013}$ Radiotherapy should be given following incomplete excision, and for the rare malignant ependymomas.

Astrocytomas in adults usually infiltrate the surrounding spinal cord. Macroscopic excision can only be achieved in a small proportion of patients, and a biopsy alone is often all that can be achieved. Recurrence is common and radiotherapy will usually be given, although there is debate as to whether very low grade tumours require radiotherapy. The average survival after surgery and radiotherapy is 76 months for low grade, and six months for high grade tumours. ${ }^{131433}$

\section{Conclusion}

In most cases of conus and cauda equina tumours the symptoms and signs will suggest the need for further investigation. Almost one 


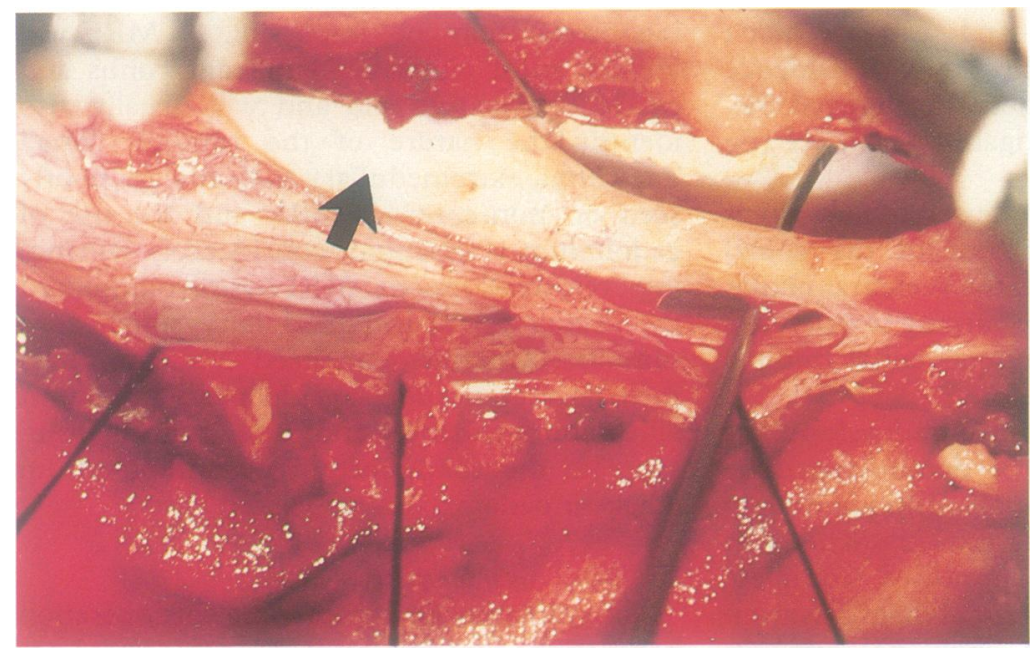

Figure 2 Per-operative photograph, same patient as Figure 1 (patient lying supine, head to the right of the picture). The dura is retracted by silk sutures to reveal an enlarged filum terminale (arrow) containing dermoid tumour. The dissector lies behind the thickened caudal extent of the filum.

fifth of patients, all with small intramedullary tumours, present diagnostic difficulty, and a higher level of clinical suspicion is required in patients with isolated symptoms of back pain, sphincter disturbance, or, for example, weakness. Myelography will demonstrate an abnormality in most cases, but MRI is now the imaging modality of choice. Excision of most extramedullary tumours is relatively straightforward with good results and permanent cure. The problems associated with intramedullary tumours are complex, and management decisions must reflect the individual needs of the patient.

We thank Professor D I Graham and Mr R Johnstone and Dr D Hadley of the Institute of Neurological Sciences, Glasgow for their professional help and advice in preparing this manuscript.

1 Ayres WW. Ependymoma of the cauda equina. A report of the clinicopathologic aspects and follow-up studies of 18 cases. Milit Med 1958;122:10-35.

2 Dejong RN. The neurologic examination incorporating the fundamentals of neuroanatomy and neurophysiology, 3rd ed. New York, Evanston and London, Hoeber Medical Division, Harper and Row 1967;800-1.

3 Norston CW, Kernohan JW, Love JG. One hundred primary caudal tumours. $\mathcal{f}$ Amer Med Ass 1961;178: 1071-7.

4 Levitt P, Ransohoff J. The differential diagnosis of tumours of the conus medullaris and cauda-equina. In: Vinken PJ, Bruyn GW, eds. Handbook of clinical neurology, Amster-
dam: North-Holland 1975;19:77-90.

5 Adams CBT. Spinal surgery. In: Dickson RA, ed. 1990; London: Butterworths.
6 Fearnside MR, Adams CBT. Tumours of the cauda-equina. f Neurol Neurosurg Psychiatry 1978;41:24-31.

7 Alter M. Statistical aspect of spinal cord tumours. In: Vinken Bruyn GW, eds. Handbook of clinical neurology, Amsterdam, North Holland 1975;19:1-22.

8 Sloof JL, Kernohan JW, MacCarty CS. Primary medullary tumours of the spinal cord and filum terminale. PhiladelphiaLondon, WB Saunders, 1964.

9 Cooper PR. Outcome after operative treatment of intramedullary spinal cord tumour in adults: intermediate and long-term results in 51 patients. Neurosurgery 1989;25: 855-9.

10 Solero CL, Fornari M, Giombini S, Lasio G, Oliveri G, Cimino C, Pluchino F. Spinal meningiomas: review of 174 operated cases. Neurosurgery 1989;25(2):153-60.

11 Cooper PR, Epstein F. Radical resection of intramedullary spinal cord tumours in adults. Recent experiences in 29 spinal cord tumours in adults. Recent
patients. $¥$ Neurosurg 1985;63:492-9.

12 Nittner $K$. Spinal meningiomas, neurinomas and neurofibromas and hourglass tumours. In: Vinken PJ, Bruyn $\mathrm{BW}$, eds. Tumours of the spine and spinal cord, part III Handbook of clinical neurology, Amsterdam, North Holland: $1976 ; 20: 177-322$

13 Guidetti B, Mercari S, Vagnozzi R. Long-term results of surgical treatment of 129 intramedullary spinal gliomas. $\mathcal{F}$ Neurosurg 1981;54:323-30.

14 Cohen AR, Wisoff JH, Allen C, Epstein F. Malignan astrocytomas of the spinal cord. $\mathcal{f}$ Neurosurg 1989;70 $50-4$.

15 Arseni C. Spinal cord dysembryoplastic tumours. Psychiat Neurol Neurochir 1968;71:509-19.

16 Matson DD. Neurosurgery of infancy and childhood, 2nd ed. Springfield Il, Thomas CC, 1969.

17 Takendri J, Ohta T, Kajikawa H. Congenital tumours of the spinal cord. In: Vinken PJ, Bruyn GW, eds. Handbook of spinal cord. In: Vinken PJ, Bruyn GW, eds. Handbook of clinical neurok

18 Lunardi P, Missori P, Gagliardi FM, Fortuna A. Long-term, results of surgical treatment of spinal dermoid and epidermoid tumours. Neurosurgery 1989;25:860-4.

19 Epstein BS. The spine: a radiological text and atlas, 3rd ed. Philadelphia, PA: Lea and Febiger, 1969:625

20 Nittner K. Raumbeengende Prozesse in Spinal Kanal. In Krenkel W, Olivecrona H, Tonnis W, eds: Handbook der Neurochirugie, vol VII(2), Berlin Heidelberg, New York Springer: 1982.

21 Guidetti B, Fortuna A. Differential diagnosis of intramedullary and extramedullary tumours. In: Vinken PJ, Bruyn GU, eds. Handbook of clinical neurology, Amsterdam: North Holland, 1975;19:51-75.

22 Levy W, Latchaw J, Hahn JF, Buphinda S, Bay J, Dohn D. Spinal neurofibromas: a report of 66 cases and a compariso

23 Campbell FG. Painless tumours of the cauda-equina. Neurology (Minneapolis) 1963;13:341-3.

24 Garfield J, Lytle SN. Urinary presentation of cauda-equina lesions without neurological symptoms. $\operatorname{Br} \mathcal{f}$ Urology 1970;42:551-4

25 Bailey IC. Dermoid tumours of the spinal cord. $\mathcal{F}$ Neurosurg 1970;33:676-81.

26 Arseni C, Marcsis M. Tumours of the lower spinal cord associated with increased intracranial pressure and papilloedema. I Neurosurg 1967;27:105-10.

27 Gardner WJ, Spitter DK, Whitten C. Increased intracrania pressure caused by increased protein content in the pressure caused by increased protein content in the
cerebro-spinal fluid. New Eng $\mathcal{Y}$ Med 1954;250:932-6.

28 Nassar SI, Correll JW. Subarachnoid haemorrhage due to spinal cord tumours. Neurology (Minneapolis) 1968; 18:87-94.

29 Shapiro R. Myelography. London: Year Book Medical Publishers, 1975:284-5.

30 Bronen RA, Size G. MR imaging control agents: Theory and Application to the CNS. $\mathcal{F}$ Neurosurg 1990;73: 820-39.

31 Penisson-Besnier I, Guy C, Gandon Y. Intramedullary epidermoid cyst evaluated by computed tomographic scan and magnetic resonance imaging: case report. Neurosurg 1989;25:955-9.

32 Philippon J, Corna PR, Grob R, Rivierez M. Les meningiomes ricdirantes. Neurochirurgie 1986;32(Suppl): 54-62.

33 Levy W, Bay J, Dohn D. Spinal cord meningioma. $f$ Neurosurg 1982;57:804-12. 